\title{
Presencia de Poecilia mexicana Steindachner en un estuario hiperhalino temporal del golfo de México
}

\section{Presence of Poecilia mexicana Steindachner in a temporary hyperhaline estuary of the Gulf of Mexico}

\author{
Rafael Chávez-López*, Arturo Rocha-Ramírez y Ángel Morán-Silva \\ $\begin{array}{lll}\text { (iD) } 0000-0002-0936-7365 & \text { (ID) } 0000-0002-6105-4294 & \text { (ID) } 0000-0002-7545-2269\end{array}$
}

Lab. Ecología Estuarina, Facultad de Estudios Superiores Iztacala, Universidad Nacional Autónoma de México, Tlalnepantla, Estado de México, México. rafaelcl@unam.mx*Autor para correspondencia.

\section{RESUMEN}

$\mathrm{E}$ $\mathrm{n}$ esta contribución se registra por primera vez a Poecilia mexicana en un estuario ciego bajo condiciones de hiperhalinidad en el golfo de México y se analizan diversas características ecológicas de la especie. Los especímenes, 170 en total (128 hembras y 42 machos), se recolectaron en mayo de 2013 en el estuario Laguna El Llano, Veracruz, México, el cual presentó aguas cálidas $\left(31,4^{\circ} \mathrm{C}\right)$, bien oxigenadas $(9,45 \mathrm{mg} / \mathrm{L})$, transparentes, e hiperhalinas (promedio $\left.73 \mathrm{UPS}\right)$. Las hembras se recolectaron en un intervalo de tallas de 4,28-59,21 mm de longitud patrón y de 0,04-5,48 g en peso; los machos se colectaron en un intervalo de tallas de 15,7351,41 mm LP y de 0,091-2,97 g en peso. El intervalo de talla más numeroso fue de 10-29 mm de longitud patrón. Las hembras presentaron un crecimiento alométrico negativo; los machos presentaron un crecimiento isométrico. La hiperhalinidad del agua no pareció afectar el proceso de reproducción de P. mexicana, pues se encontraron hembras maduras con ovocitos, huevos y embriones, algunas de ellas con superfetación. La fecundidad se registró entre 12-179 ovocitos/hembra, 8-162 huevos/hembra y 29-72 embriones/hembra. El factor de condición se correlacionó positivamente con la longitud patrón y el peso. Esta especie se puede clasificar como un consumidor detritívoro que complementa su dieta con proporciones mínimas de diatomeas.

PALABRAS CLAVE: Laguna El Llano, Poeciliidae, Topote del Atlántico, Veracruz.

\begin{abstract}
I n this contribution, Poecilia mexicana is recorded for the first time in a blind estuary study under hyperhalin conditions in the Gulf of Mexico and various ecological characteristics of the species are analyzed. 170 specimens in total (128 females and 42 males), were collected in May 2013 in the Laguna El Llano estuary, Veracruz, Mexico, which presented warm waters $\left(31.4{ }^{\circ} \mathrm{C}\right)$, well-oxygenated $(9.45 \mathrm{mg} / \mathrm{L})$, transparent, and hyperhaline (average $73 \mathrm{UPS})$. Females were collected in a size range of 4.28-59.21 mm in standard length and 0.04-5.48 g by weight; males were collected in a size range of 15.73-51.41 mm LP and 0.091-2.97 g by weight. Largest size range was 10-29 mm standard length. The females presented a negative allometric growth; the males presented an isometric growth. Hyperhalinity of the water did not seem to affect the reproduction process of $P$. mexicana, since mature females were found with oocytes, eggs, and embryos, some of them presenting superfetation. Fertility was recorded between 12-179 oocytes/female, 8-162 eggs/female and 29-72 embryos/ female. Condition factor was positively correlated with the standard length and weight. This species can be classified as a detritivorous consumer that supplements its diet with minimal proportions of diatoms.
\end{abstract}

KEYWORDS: Laguna El Llano, Poeciliidae, Shortfin Molly, Veracruz. 


\section{INTRODUCCIÓN}

Los estuarios son ecosistemas de alta productividad. Su dinámica ambiental está controlada por combinaciones temporales de factores físicos, hidrológicos y meteorológicos que determinan patrones ecológicos cambiantes (Brito, 2012), por lo que se ven como mosaicos naturales compuestos por distintos hábitats que aportan servicios ecosistémicos a las poblaciones de peces como zonas de refugio, crianza y alimentación (Needles et al., 2015). Las especies marinas son las más numerosas en las comunidades estuarinas de peces, que ocupan estos hábitats en las fases jóvenes de sus ciclos de vida; en contraste, se afirma que las especies de origen dulceacuícola se encuentran en número reducido y en abundancias bajas solo cuando hay aportes consistentes de agua dulce (Potter et al., 2015), por lo que se califican como especies en tránsito o visitantes accidentales (Whitfield, 2015).

Sin embargo, varias especies de la familia Poeciliidae son capaces de colonizar estuarios desde la costa Atlántica de los Estados Unidos hasta Argentina e islas del mar Caribe. En particular, el género Poecilia es nativo de hábitats dulceacuícolas y algunas especies como $P$. sphenops, P. latipinna y P. mexicana se han registrado en otros estuarios del golfo de México (Rodríguez-Varela et al., 2010; VegaCendejas et al., 2013; Chávez-López et al., 2015). Hasta ahora, no se ha reconocido la tolerancia a la salinidad de $P$. mexicana, por lo que en este escrito se describen características de la ecología de esta especie dulceacuícola en el estuario Laguna El Llano de Veracruz, México, bajo condiciones de hiperhalinidad.

\section{MATERIALES Y MÉTODOS}

\section{Área de estudio}

El estuario Laguna El Llano (ELEL) se localiza a $19^{\circ} 40^{\prime} 05^{\prime}$ ' N y $96^{\circ} 23^{\prime} 54^{\prime \prime} \mathrm{O}$, en el municipio de Actopan, Veracruz (Figura 1). Es un cuerpo de agua de 226 ha y la profundidad en los márgenes internos es menor de $1 \mathrm{~m}$ de profundidad, pero en el canal central alcanza un intervalo de profundidad que varía estacionalmente de 2 a $4 \mathrm{~m}$.

El clima es cálido húmedo con lluvias en verano (Aw2) (García, 2004), la precipitación anual media es de $1286 \mathrm{~mm}$ y la temperatura media anual de $24^{\circ} \mathrm{C}$. En la región se diferencian tres estaciones climáticas: la cálida transcurre entre abril y junio; la de lluvias, entre julio y octubre, y la estación fría sucede de noviembre a marzo (Morán-Silva et al., 2005). Precisamente en esta estación se forma una barra

\section{INTRODUCTION}

Estuaries are highly productive ecosystems. Their environmental dynamics are controlled by temporal combinations of physical, hydrological, and meteorological factors that are determined to change ecological patterns (Brito, 2012), which is why they are seen as natural mosaics made up of different habitats that provide ecosystem services to fish stocks as a refuge, breeding, and feeding areas (Needles et al., 2015). Marine species are the most numerous in estuarine fish communities, which occupy these habitats in the young phases of their life cycles; in contrast, it is stated that species of freshwater origin are in reduced numbers and low abundances only when there are consistent contributions of freshwater (Potter et al., 2015), which is why they are classified as species in transit or as accidental visitors (Whitfield, 2015).

However, several species in the family Poeciliidae are capable of colonizing estuaries from the Atlantic coast of the United States to Argentina and islands in the Caribbean Sea. In particular, the genus Poecilia is native to freshwater habitats and some species such as $P$. sphenops, $P$. latipinna and $P$. mexicana have been recorded in other estuaries in the Gulf of Mexico (Rodríguez-Varela et al., 2010; Vega-Cendejas et al., 2013; Chávez-López et al., 2015). Until now, the tolerance to salinity of $P$. mexicana has not been recognized, so this paper describes characteristics of the ecology of this freshwater species in the Laguna El Llano estuary of Veracruz, Mexico, under hyperhalinity conditions.

\section{MATERIALS AND METHODS}

\section{Study area}

The Laguna El Llano (ELEL) estuary is located at $19^{\circ} 40^{\prime} 05^{\prime \prime} \mathrm{N}$ and $96^{\circ} 23^{\prime} 54^{\prime \prime} \mathrm{W}$, in the municipality of Actopan, Veracruz (Figure 1). It is a 226 ha body of water and the depth at the internal margins is less than $1 \mathrm{~m}$ deep, but in the central channel, it reaches a depth interval that varies seasonally from 2 to $4 \mathrm{~m}$.

The climate is warm humid with rains in summer (Aw2) (García, 2004), the average annual precipitation is $1286 \mathrm{~mm}$ and the average annual temperature is $24{ }^{\circ} \mathrm{C}$. Three climatic seasons are different in the region: the warm one runs between April and June, the rainy season between July and October, and the cold season occurs from November to March (Morán-Silva et al., 2005). 


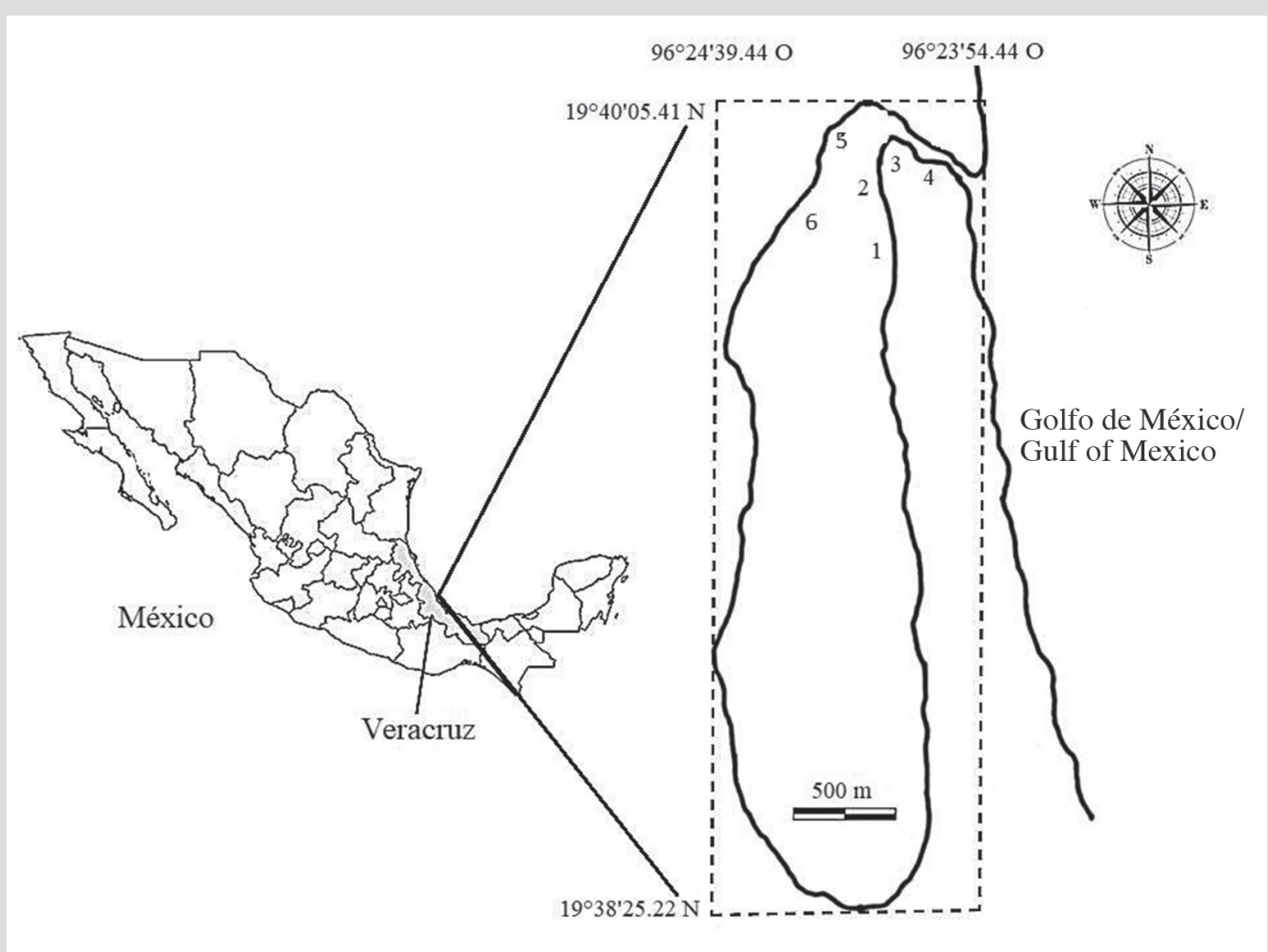

Figura 1. Ubicación del estuario Laguna El Llano (ELEL), municipio de Actopan, Veracruz, México. Los números indican los sitios de muestreo (SM1-SM6) en mayo de 2013.
Figure 1. Location of the Laguna El Llano estuary (ELEL), Actopan municipality, Veracruz, Mexico. The numbers indicate the sampling sites (SM1-SM6) in May 2013.. arenosa en la boca de comunicación del estuario debido a procesos sedimentarios costeros. Por esta característica geomorfológica, aquí se usa la definición de estuario de Potter et al. (2010), que alude al aislamiento temporal del estuario $\mathrm{y}$ a la potencialidad de que este evento provoque condiciones de hiperhalinidad.

Los especímenes de $P$. mexicana solo se colectaron en mayo de 2013. Este fue el muestreo inicial de una investigación sobre la comunidad de peces de ELEL que se realizó entre ese mes y mayo de 2014. Las recolectas se realizaron en seis sitios de muestreo (SM) cercanos a riberas de mangle rojo Rhizophora mangle y de mangle negro Avicennia germinans, caracterizados por fondos lodosos y cercanos a arrecifes del ostión Crassostrea virginica. El muestreo se restringió a profundidades menores de 1,2 m; no se extendió hacia la zona sur del estuario debido a lo somero de la columna de agua (menos de $30 \mathrm{~cm}$ ) y a la consistencia lodosa ( $>1 \mathrm{~m}$ ) del horizonte superior del sustrato. Los SM se ubicaron con un GPS Garmin 10X GPS. También se registró el oxígeno disuelto $(\mathrm{mg} / \mathrm{L})$ y la temperatura del agua $\left({ }^{\circ} \mathrm{C}\right)$ con un oxímetro Oakton DO 300 con precisión de $0,1{ }^{\circ} \mathrm{C}$; salinidad (UPS), con un refractómetro Vista A366ATC con
Precisely at this season, a sandy bar forms at the mouth of the estuary due to coastal sedimentary processes. For this geomorphological feature, the definition of the estuary by Potter et al. (2010) is used here. That alludes to the temporary isolation of the estuary and the potential that this event causes hyperhalinity conditions.

The specimens of $P$. mexicana were only collected in May 2013. This was the initial sampling of an investigation on the ELEL fish community that was carried out between that month and May 2014. The collections were made in six sampling sites (SM) near the banks of the red mangrove Rhizophora mangle and the black mangrove Avicennia germinans, characterized by muddy bottoms and close to reefs of the Crassostrea virginica oyster. Sampling was restricted to depths less than $1.2 \mathrm{~m}$; it did not extend to the southern part of the estuary due to the shallowness of the water column (less than $30 \mathrm{~cm}$ ) and the muddy consistency ( $>1 \mathrm{~m}$ ) of the upper horizon of the substratum. The SMs were located with a Garmin 10X GPS. Dissolved oxygen $(\mathrm{mg} / \mathrm{L})$ and water temperature $\left({ }^{\circ} \mathrm{C}\right)$ was also recorded with an Oakton DO 300 oximeter with $0.1{ }^{\circ} \mathrm{C}$ accuracy; salinity (UPS) with a Vista 
precisión de 0,1 UPS; turbidez, con un turbidímetro La Motte 2020 (UNT) con precisión de 0,1 UNT; pH, con un pHmetro Oakton pH 110 Meter con precisión de 0,1 unidad de pH, y profundidad $(\mathrm{cm})$, con una sonda Echotest II Plastimo con precisión de $0,1 \mathrm{~cm}$. Las categorías de salinidad se definieron con base en la propuesta del Sistema de Venecia (Ito, 1959).

Los especímenes fueron capturados usando una red de arrastre tipo chinchorro de $25 \mathrm{~m}$ de largo por $2 \mathrm{~m}$ de alto con una luz de malla de $6,5 \mathrm{~mm}$. Se procuró que el área de colecta en cada SM fuese de $300 \mathrm{~m}^{2}$; solo en la SM 2 fue de $125 \mathrm{~m}^{2}$. Todos los especímenes colectados se colocaron en hielo y luego en frascos con etanol al $70 \%$. En el laboratorio se lavaron, se fijaron con formalina al $5 \%$ y se almacenaron en etanol al $70 \%$. Los especímenes se identificaron con Álvarez del Villar (1970) y Miller et al. (2009). Cada pez se midió con una escala en longitud patrón (LP) hasta $0,01 \mathrm{~mm}$. El peso individual (P), de las gónadas (PG) y del hepatopáncreas $(\mathrm{PH})$ se midieron con una balanza electrónica Cole-Parmer Simmetry con precisión de $0,001 \mathrm{~g}$. La diferencia de P menos PG se tomó como el peso somático (PS).

\section{Análisis estadístico}

Se estableció la estructura por tallas separando a los organismos en intervalos de $10 \mathrm{~mm}$ de longitud. Las tallas se definieron usando el método de análisis de frecuencias de Pope et al. (2010). El crecimiento relativo se evaluó con base en la relación biométrica LP vs. P, donde LP fue la variable independiente. Esta relación biométrica se ajustó usando una función potencial $(\mathrm{Y}=\mathrm{aX})$, donde $a$ es la ordenada al origen (coeficiente de crecimiento inicial) y $b$ es la pendiente (coeficiente de crecimiento o también llamado coeficiente de alometría). Los valores de LP y P se transformaron a logaritmos y el resultado de la relación lineal se ajustó con una regresión de mínimos cuadrados usando $\mathrm{P}$ como variable dependiente (Le Creen, 1951; Ricker, 1975). El grado de asociación entre las variables se estableció mediante el coeficiente de determinación $\left(\mathrm{r}^{2}\right)$. Se calcularon las relaciones LP vs. P para toda la muestra de peces y por cada sexo.

Para probar la hipótesis de crecimiento isométrico se usó una prueba de $t$ student probando Ho: $b=3$ contra $\mathrm{H} 1: \mathrm{b} \neq 3$ con $n-1$ grados de libertad y un nivel de significancia de $\mathrm{P}=0,05$. De la misma manera, para determinar si ocurrieron diferencias entre los valores de $\mathrm{b}$ de machos y hembras, se probó Ho: $b_{\text {machos }}-b_{\text {hembras }}=0$, lo que indica diferencias entre las pendientes; contra $\mathrm{H} 1: \mathrm{b}_{\text {machos }}-\mathrm{b}_{\text {hembras }} \neq 0$, que indica diferencias en el valor de $\mathrm{b}$ entre los grupos. Además se usó una prueba de ANCOVA para comparar las
A366ATC refractometer with 0.1 UPS accuracy; turbidity with a La Motte 2020 (UNT) turbidimeter with 0.1 UNT accuracy; $\mathrm{pH}$ with an Oakton $\mathrm{pH} 110$ Meter with $0.1 \mathrm{pH}$ unit accuracy, and the depth $(\mathrm{cm})$ was recorded with an Echotest II Plastimo probe with a precision of $0.1 \mathrm{~cm}$. The salinity categories were defined based on the proposal of the Venice System (Ito, 1959).

Specimens were captured using a $25 \mathrm{~m}$ long by $2 \mathrm{~m}$ high seine net with a $6.5 \mathrm{~mm}$ mesh span. It was tried that the collection area in each SM was $300 \mathrm{~m}^{2}$; only in SM 2 it was $125 \mathrm{~m}^{2}$. All the collected specimens were placed on ice and then in bottles with $70 \%$ ethanol. In the laboratory they were washed, fixed with $5 \%$ formalin and stored in $70 \%$ ethanol. The specimens were identified with Álvarez del Villar (1970) and Miller et al. (2009). Each fish was measured with a standard length scale (LP) up to $0.01 \mathrm{~mm}$. The individual weight $(\mathrm{P})$, the gonads (PG), and the hepatopancreas $(\mathrm{PH})$ were measured with a Cole-Parmer Simmetry electronic balance with a precision of $0.001 \mathrm{~g}$. The difference of P minus PG was taken as the somatic weight (PS).

\section{Statistical analysis}

The size structure was established by separating the organisms in $10 \mathrm{~mm}$ length intervals. The sizes were defined using the frequency analysis method of Pope et al. (2010). Relative growth was evaluated based on the biometric relationship LP vs. P, where LP was the independent variable. This biometric relationship was adjusted using a potential function $\left(\mathrm{Y}=\mathrm{aX} \mathrm{X}^{\mathrm{b}}\right)$, where $a$ is the ordinate to the origin (initial growth coefficient) and $b$ is the slope (growth coefficient or also called coefficient of allometry). The LP and P values were transformed into logarithms and the result of the linear relationship was adjusted with a least-squares regression using $\mathrm{P}$ as the dependent variable (Le Creen, 1951; Ricker, 1975). The degree of association between the variables was established utilizing the determination coefficient $\left(\mathrm{r}^{2}\right)$. The LP vs. P ratios were calculated for the entire fish sample and each sex.

To test the isometric growth hypothesis, a student's t-test was used, testing Ho: $b=3$ against $\mathrm{H} 1$ : $\mathrm{b} \neq 3$ with $\mathrm{n}-1$ degrees of freedom and a significance level of $\mathrm{P}=0.05$. In the same way, to determine if differences occurred between the values of $b$ of males and females, Ho was tested: $b_{\text {males }}-b_{\text {females }}=0$, indicating differences between the slopes, against $H 1: b_{\text {males }}-b_{\text {females }} \neq 0$, indicating 
diferencias entre las relaciones biométricas de LP vs. P entre sexos usando LP como covariado. Todos los procedimientos estadísticos se calcularon con el programa PAST (Hammer et al., 2001) con significancia de $\mathrm{P}=0,05$.

Se estimó el factor de condición de Fulton K, que se usó para comparar el bienestar de los peces con la suposición de que un pez más pesado a una longitud determinada tiene mejor condición (Le Creen, 1951), de acuerdo con la ecuación:

$$
\mathrm{K}=100 \frac{\mathrm{PT}}{\mathrm{LP}^{\mathrm{b}}}
$$

Donde,

$\mathrm{P}=$ peso de cada pez en $\mathrm{g}$

$\mathrm{LP}=$ longitud patrón individual en $\mathrm{mm}$

b se usó como la constante de crecimiento relativo y el factor 100, para escalar K a la unidad. Este modelo se aplicó por separado al grupo de machos y de hembras, usando el valor respectivo del coeficiente de alometría $b$.

Los valores individuales de $\mathrm{K}$ de machos $\mathrm{y}$ hembras se correlacionaron a sus valores respectivos de LP y P como variables independientes. El Índice Gonadosomático (IGS, De Vlaming et al., 1982) de machos y hembras también se correlacionó con LP, P, PS, PG y PH (Vazzoler, 1996). En todos los casos se usó la prueba de correlación de Pearson con $\mathrm{P}=0,05$.

La madurez gonádica y los estadios de desarrollo embrionario se definieron con base en los criterios de Riesch et al. (2011). En las gónadas de 50 hembras se contaron los ovocitos y embriones. Con estos registros se estimó la fecundidad.

La composición de la dieta se determinó con el método numérico de rejilla (Trujillo-Jiménez y Toledo, 2007). Los tipos alimentarios se identificaron al nivel taxonómico más preciso posible. Las especies de diatomeas se identificaron con Prescott (1978) y Bellinger y Sigee (2010). La composición de la dieta entre tallas se comparó con una prueba ANDEVA de una vía con $\mathrm{P}=0,05$.

\section{RESULTADOS}

Los registros hidrológicos de mayo de 2013 correspondieron a agua cálida, ligeramente alcalina, bien oxigenada e hiperhalina (Tabla 1). En junio de 2013, la barra arenosa se desintegró y se reanudó el intercambio de agua entre el estuario con la plataforma marina. differences in the value of $\mathrm{b}$ between the groups. Also, an ANCOVA test was used to compare the differences between the biometric relationships of LP vs. P between sexes, using LP as a covariate. All statistical procedures were calculated with the PAST program (Hammer et al., 2001) with a significance of $\mathrm{P}=0.05$.

The Fulton $\mathrm{K}$ condition factor was estimated, which was used to compare the welfare of the fish with the assumption that a heavier fish at a given length has a better condition (Le Creen, 1951), according to the equation:

$$
\mathrm{K}=100 \frac{\mathrm{PT}}{\mathrm{LP}^{\mathrm{b}}}
$$

Where,

$\mathrm{P}=$ weight of each fish in $\mathrm{g}$

$\mathrm{LP}=$ individual standard length in $\mathrm{mm}$

$\mathrm{b}$ was used as the relative growth constant and factor 100 is used to scale $\mathrm{K}$ to unity. This model was applied separately to the group of males and females, using the respective value of the allometric coefficient $b$.

The individual values of $\mathrm{K}$ of males and females were correlated to their respective values of LP and P as independent variables. The Gonadosomatic Index (IGS, De Vlaming et al., 1982) of males and females was also correlated to LP, P, PS, PG and PH (Vazzoler, 1996). In all cases the Pearson's correlation test was used with $\mathrm{P}=0.05$.

Gonadic maturity and stages of embryonic development were defined based on the criteria of Riesch et al. (2011). Oocytes and embryos were counted in the gonads of 50 females. With these records, fertility was estimated.

The composition of the diet was determined with the numerical grid method (Trujillo-Jiménez and Toledo, 2007). Food types were identified at the most precise taxonomic level possible. Diatom species were identified with Prescott (1978) and Bellinger and Sigee (2010). Diet composition between sizes was compared with a one-way ANOVA test with $\mathrm{P}=0.05$.

\section{RESULTS}

The hydrological records for May 2013 corresponded to warm, slightly alkaline, well-oxygenated and hyperhaline water (Table 1). In June 2013 the sandy bar disintegrated and the exchange of water between the estuary and the marine platform resumed. 
Tabla 1. Registros hidrológicos en ELEL para mayo de 2013 durante la fase de boca estuarina cerrada. UNT: Unidades Nefelométricas de Turbidez, UPS: Unidades Prácticas de Salinidad, DS: Desviación Estándar.
Table 1. Hydrological records in ELEL for May 2013 during the closed estuarine inlet phase. UNT: Nephelometric Turbidity Units, UPS: Practical Salinity Units, DS: Standard Deviation.

\begin{tabular}{|l|c|c|c|c|c|c|c|}
\cline { 2 - 9 } \multicolumn{1}{c|}{} & SM 1 & SM 2 & SM 3 & SM 4 & SM 5 & SM 6 & Promedio/Average \pm DS \\
\hline $\mathrm{pH}$ & 7.59 & 8.49 & 7.6 & 7.61 & 7.6 & 7.62 & $7.75 \pm 0.36$ \\
\hline $\mathrm{O}_{2} \mathrm{mg} / \mathrm{L}$ & 8.22 & 8.91 & 10.2 & 9.5 & 9.86 & 10.01 & $9.45 \pm 0.76$ \\
\hline $\mathrm{T}^{\circ} \mathrm{C}$ & 30.2 & 31.9 & 31.5 & 31.8 & 31.9 & 31.4 & $31.45 \pm 0.65$ \\
\hline Turbidez/Turbidity (UNT) & 23 & 19.1 & 13.6 & 10.37 & 10.45 & 29.1 & $17.60 \pm 7.52$ \\
\hline Salinidad/Salinity (UPS) & 71 & 74 & 72 & 70 & 76 & 76 & $73.17 \pm 2.56$ \\
\hline
\end{tabular}

Poecilia mexicana solo se colectó en mayo de 2013 y fue la especie más abundante. También se obtuvieron otras tres especies: Mugil cephalus, Centropomus undecimalis y Lutjanus griseus. De los 170 individuos, 128 fueron hembras en un intervalo de LP de 4,28-59,21 $\mathrm{mm}$ y de 0,04-5,48 g P y 42 fueron machos en un intervalo de 15,73$51,41 \mathrm{~mm}$ LP y de 0,091-2,97 g P. Las clases de talla de 10-19 y 20-29 mm LP fueron las más numerosas. Los organismos de estos intervalos agruparon al 90,5\% de la abundancia de los machos y al 79,7 \% de la abundancia de las hembras (Tabla 2).

Tabla 2. Clases de talla y abundancia de P. mexicana en ELEL en mayo de 2013.

\begin{tabular}{|l|l|c|c|c|c|c|c|}
\cline { 2 - 8 } \multicolumn{1}{c|}{} & \multicolumn{1}{c|}{ Clase de talla/Size class } & I & II & III & IV & V VI & V \\
\cline { 2 - 8 } & \multicolumn{1}{c|}{ LP mm } & $\mathbf{1 - 9}$ & $\mathbf{1 0 - 1 9}$ & $\mathbf{2 0 - 2 9}$ & $\mathbf{3 0 - 3 9}$ & $\mathbf{4 0 - 4 9}$ & $\mathbf{5 0 - 5 9}$ \\
\hline \multirow{2}{*}{ Abundancia/Abundance } & Machos/Males & 0 & 6 & 32 & 2 & 1 \\
& Hembras/Females & 5 & 46 & 56 & 16 & 2 \\
\hline
\end{tabular}

Las hembras de $P$. mexicana presentaron crecimiento alométrico negativo $(\mathrm{P}<0,001)$ mientras que los machos tendieron hacia un crecimiento isométrico $(\mathrm{P}<0,001)$ (Tabla 3). Los incrementos en peso no fueron diferentes entre machos y hembras $(\mathrm{P}>0,05)$.
Poecilia mexicana was only collected in May 2013 and was the most abundant species. Three other species were also obtained: Mugil cephalus, Centropomus undecimalis, and Lutjanus griseus. Of the 170 individuals, 128 were females in an LP range of 4.28-59.21 mm and 0.04-5.48 g P and 42 were males that presented in an interval of $15.73-51.41 \mathrm{~mm} \mathrm{LP}$ and $0.091-2.97 \mathrm{~g}$ P. The size classes of 10-19 and 20-29 mm LP were the most numerous. The organisms from these ranges grouped $90.5 \%$ of the abundance of males and $79.7 \%$ of the abundance of females (Tabla 2).

Table 2. Size classes and abundance of $P$. mexicana in ELEL in May 2013.

Females of $P$. mexicana presented negative allometric growth $(\mathrm{P}<0.001)$ while males tended towards isometric growth $(\mathrm{P}<0.001)$ (Table 3$)$. The weight increases were not different between males and females $(\mathrm{P}>0.05)$.

Tabla 3. Parámetros del modelo de crecimiento relativo (Peso $\mathrm{P}$ vs. Longitud Patrón LP) para hembras, machos y todos los individuos de $P$. mexicana en ELEL.

Table 3. Parameters of the relative growth model (Weight $P$ vs. Standard Length LP) for females, males, and all individuals of $P$. mexicana in ELEL.

\begin{tabular}{|l|c|c|c|c|c|c|c|c|c|}
\hline $\begin{array}{l}\text { Grupo/ } \\
\text { Group }\end{array}$ & $\mathbf{n}$ & $\begin{array}{c}\text { LPmin-LPmax } \\
(\overline{\boldsymbol{X}} \pm \mathbf{D E})\end{array}$ & $\begin{array}{c}\text { Pmin-Pmax } \\
(\overline{\boldsymbol{X}} \pm \mathbf{D E})\end{array}$ & $\mathbf{A}$ & $\mathbf{I C}$ & $\mathbf{b}$ & $\mathbf{I C}$ & $\begin{array}{c}\text { Relación prueba t/ } \\
\text { Test relationship t } \\
(\boldsymbol{P}<\mathbf{0 . 0 5})\end{array}$ \\
\hline $\begin{array}{l}\text { Hembras/ } \\
\text { Females }\end{array}$ & 128 & $\begin{array}{c}4.28-59.21 \\
(22.62 \pm 8.985)\end{array}$ & $\begin{array}{c}0.04-5.48 \\
(0.42 \pm 0.624)\end{array}$ & -3.073 & $(-3.649,-2.33)$ & 1.878 & $(1.342,2.305)$ & 0.67 & $\begin{array}{l}\text { Alométrico negativo/ } \\
\text { Negative allometric }\end{array}$ \\
$\begin{array}{l}\text { Machos/ } \\
\text { Males }\end{array}$ & 42 & $\begin{array}{c}15.0-51.41 \\
(25.01 \pm 6.82)\end{array}$ & $\begin{array}{c}0.91-2.97 \\
(0.424 \pm 0.51)\end{array}$ & -4.623 & $(-4.736,-4.381)$ & 2.914 & $(2.798,3.055)$ & 0.988 & Isométrico/Isometric \\
Todos/All & 170 & $\begin{array}{c}4.28-59.21 \\
(23.2 \pm 8.54)\end{array}$ & $\begin{array}{c}0.04-5.48 \\
(0.42 \pm 0.596)\end{array}$ & -3.194 & $(-3.744,-2.444)$ & 1.963 & $(1.424,2.35)$ & 0.697 & $\begin{array}{l}\text { Alométrico negativo/ } \\
\text { Negative allometric }\end{array}$ \\
\hline
\end{tabular}


El factor de condición $\mathrm{K}$ de las hembras se registró en un intervalo de $0,036-4,31$ (promedio $\pm \mathrm{DE}: 0,33 \pm 0,488$ ) y para los machos, de 0,86-2,64 (promedio $\pm \mathrm{DE}: 0,405 \pm 0,464$ ). $\mathrm{K}$ se correlacionó positivamente a LP y $\mathrm{P}$ de hembras y machos $(\mathrm{P}<0.001)$ (Figura 2a y Figura $2 \mathrm{~b}$ ).
The condition factor $\mathrm{K}$ of the females was recorded in a range of 0.036-4.31 (mean $\pm \mathrm{SD}: 0.33 \pm 0.488)$ and for males in a range of 0.86-2.64 (mean \pm SD: $0.405 \pm 0.464$ ). $\mathrm{K}$ was positively correlated to LP and $\mathrm{P}$ of females and males $(\mathrm{P}<0.001)$ (Figure 2a and Figure $2 \mathrm{~b}$ ).
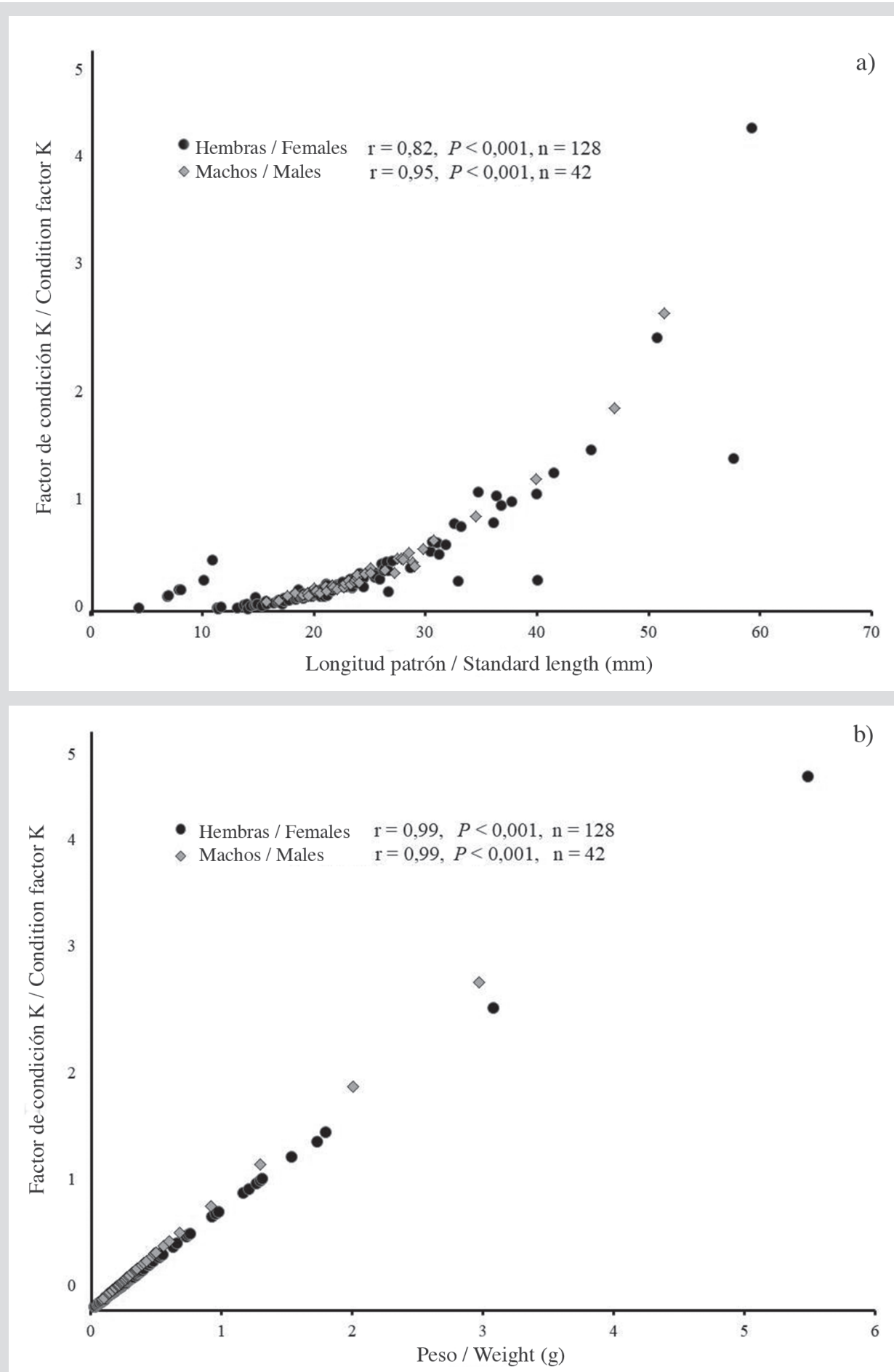

Figura 2. Factor de condición (K) por sexos de $P$. mexicana en ELEL. a) factor de condición K correlacionado a LP como variable independiente; b) factor de condición K correlacionado a P como variable independiente.
Figure 2. Condition factor $(\mathrm{K})$ by sex of $P$. mexicana in ELEL. a) condition factor $\mathrm{K}$ correlated to $\mathrm{LP}$ as an independent variable; b) condition factor $\mathrm{K}$ correlated to $\mathrm{P}$ as an independent variable. 
La LP de las hembras mostró relaciones positivas con PS, PG e IGS; por otro lado, el peso (P) tuvo una correlación alta con PS y una correlación positiva con PG, que a su vez mostró correlación positiva con IGS. Estos resultados indican que los incrementos de LP y P de las hembras no influyeron en el desarrollo gonádico. Todas las correlaciones fueron significativas $(\mathrm{P}<0,001)$. En el caso de los machos, se encontraron correlaciones positivas entre LP y P respecto a PS, PG y PH. Las correlaciones con el índice gonadosomático fueron más altas entre LP y P respecto a PG e IGS. También todas las correlaciones fueron significativas $(\mathrm{P}<0,001)$ (Tabla 4).
The female LP showed positive relationships with PS, PG, and IGS; on the other hand, weight (P) had a high correlation with PS and a positive correlation with $\mathrm{PG}$, which in turn showed a positive correlation with IGS. These results indicate that the increases of LP and P of the females did not influence the gonad development. All the correlations were significant $(\mathrm{P}<0.001)$. In the case of males, positive correlations were found between LP and $\mathrm{P}$ with respect to PS, PG, and PH. The correlations with the gonadosomatic index were higher between LP and $\mathrm{P}$ with respect to $\mathrm{PG}$ and IGS. All the correlations were also significant $(\mathrm{P}<0.001)$ (Table 4).

Tabla 4. Correlaciones entre variables somáticas y variables gonádicas de P. mexicana bajo condiciones de hiperhalinidad en ELEL.

Table 4. Correlations between somatic variables and gonadic variables of $P$. mexicana under hyperhalinity conditions in ELEL.

\begin{tabular}{|c|c|c|c|c|c|c|}
\hline & \multicolumn{3}{|c|}{ Hembras/Females } & \multicolumn{3}{|c|}{ Machos/Males } \\
\hline & $\mathbf{n}$ & $\mathbf{r}$ & $P$ & $\mathbf{n}$ & $\mathbf{R}$ & $P$ \\
\hline LP vs. PS & 50 & 0.85 & $<0.001$ & 42 & 0.79 & $<0.001$ \\
\hline LP vs. PG & 38 & 0.77 & $<0.001$ & 19 & 0.68 & $<0.001$ \\
\hline LP vs. PH & 39 & 0.56 & $<0.001$ & 20 & 0.72 & $<0.001$ \\
\hline P vs. PS & 50 & 0.91 & $<0.001$ & 42 & 0.88 & $<0.001$ \\
\hline P vs. PG & 38 & 0.64 & $<0.001$ & 19 & 0.82 & $<0.001$ \\
\hline P vs. PH & 39 & 0.63 & $<0.001$ & 20 & 0.78 & $<0.001$ \\
\hline PS vs. PG & 38 & 0.78 & $<0.001$ & 19 & 0.91 & $<0.001$ \\
\hline LP vs. IGS & 38 & 0.66 & $<0.001$ & 19 & 0.57 & $<0.001$ \\
\hline PT vs. IGS & 38 & 0.52 & $<0.001$ & 19 & 0.72 & $<0.001$ \\
\hline PS vs. IGS & 38 & 0.59 & $<0.001$ & 19 & 0.87 & $<0.001$ \\
\hline PG vs. IGS & 38 & 0.89 & $<0.001$ & 19 & 0.97 & $<0.001$ \\
\hline
\end{tabular}

De 50 hembras revisadas, 11 no mostraron desarrollo gonádico. Las hembras con algún nivel de madurez gonádica estuvieron en intervalos de 13,7-34,7 mm LP y de 0,07-1,31 g P. Diez hembras entre 36,3-50,7 mm LP cargaban productos reproductivos como huevos y embriones. De estas últimas, en cuatro se encontraron embriones en diferentes niveles de desarrollo. Finalmente, una hembra de 50,69 mm LP presentó ovocitos, huevos y embriones. La fecundidad se registró entre 12-179 ovocitos/hembra (promedio 31,3 ovocitos/hembra), 8-162 huevos/hembra (promedio 54,3 huevos/hembra) y 29-72 embriones/hembra (promedio 51,2 embriones/hembra). Solo se encontró correlación positiva entre LP de las hembras con el número de ovocitos $(\mathrm{n}=7, \mathrm{r}=0,85, \mathrm{P}<0,05)$.

La dieta de $P$. mexicana en ELEL se compuso principalmente de detritus $(97,7 \%)$. En la porción restante se encontraron diatomeas $(1,5 \%)$, algas no identificadas, foraminíferos y restos de crustáceos $(0,26 \%$ cada ítem). Las
Of 50 females reviewed, 11 did not show gonad development. Females with some level of gonad maturity were in intervals of 13.7-34.7 mm LP and 0.07-1.31 g P. Ten females between 36.3-50.7 mm LP loaded reproductive products such as eggs and embryos. Of the latter, in four embryos were found at different levels of development. Finally, a $50.69 \mathrm{~mm}$ LP female presented oocytes, eggs, and embryos. Fertility was recorded between 12-179 oocytes/female (average 31.3 oocytes/female), 8-162 eggs/female (average 54.3 eggs/female), and 29-72 embryos/female (average 51.2 embryos/female). Only positive correlation was found between female LP with the number of oocytes $(\mathrm{n}=7, \mathrm{r}=0.85, \mathrm{P}<0.05)$.

The diet of $P$. mexicana in ELEL was mainly composed of detritus $(97.7 \%)$. In the remaining portion diatoms (1.5\%), unidentified algae, foraminifera, and crustacean remains $(0.26 \%$ each item $)$ were found. The diatoms observed correspond to Navicula radiosa, $N$. 
diatomeas observadas corresponden a Navicula radiosa, $N$. chryptocephala, Diatoma hemiale, Surirella robusta var. splendida, Cymbella sp. y Nitzschia sp. La comparación de la dieta entre las clases de talla no mostró diferencias $(\mathrm{P}<0,05)$; esta composición alimentaria identifica a $P$. mexicana como un consumidor detritívoro.

\section{DISCUSIÓN}

Este es el primer registro de P. mexicana en aguas estuarinas hiperhalinas. Respecto a su tolerancia a la salinidad, Miller (1983) publicó su ocurrencia en estuarios del golfo de México. En escritos posteriores se ha registrado en salinidades menores a 15 UPS (Castro-Aguirre y MoraPérez, 1984; Rodríguez-Varela et al., 2010; Aguirre-León et al., 2014; Chávez-López et al., 2015).

La capacidad de $P$. mexicana para soportar salinidades elevadas puede explicarse por procesos bioquímicos y morfológicos descritos en otras especies, como la secreción de carbohidratos en el intestino (Laverty y Skadhauge, 2015) que provoca la precipitación del calcio y aumenta la capacidad de absorber el cloruro de sodio de las aguas hipersalinas (Whittamore, 2012). Otras investigaciones consideran la reducción de la permeabilidad branquial mediante la regulación de los niveles de proteínas aquaporinas en los epitelios branquiales (Tipsmarck et al., 2010; Verkman, 2012), que se pueden relacionar con cambios en las tasas de ingestión de agua que se incrementan en los peces que colonizan aguas salinas (Nordlie, 2006). Otras evidencias indican que disminuye la permeabilidad iónica de la superficie corporal y en las células secretoras de iones de las branquias, que son esenciales para eliminar grandes cantidades de sales en hábitats marinos e hiperhalinos (González, 2012).

La hiperhalinidad del agua no limitó la reproducción de P. mexicana. La evidencia aportada por las hembras al presentar ovocitos y embriones demuestra el uso de energía para procesos reproductivos, a pesar de que se propone que bajo condiciones de estrés ambiental el presupuesto energético se reorienta hacia el mantenimiento fisiológico basal (Stearns, 1992). Incluso los promedios del número de ovocitos (31,3 ovocitos/hembra) y de huevos (54,3 huevos/hembra) fueron similares a los encontrados en una laguna costera oligohalina de la región (ChávezLópez et al., 2015). Además, tanto el factor de condición como el peso gonádico se correlacionaron positivamente con los incrementos de longitud y de peso. Los intervalos chryptocephala, Diatoma hemiale, Surirella robusta var. splendida, Cymbella sp., and Nitzschia sp. A comparison of diet between length classes showed no difference $(\mathrm{P}<0.05)$; this food composition identifies P. mexicana as a detritivorous consumer.

\section{DISCUSSION}

This is the first record of P. mexicana in hyperhaline estuarine waters. Regarding its tolerance to salinity, Miller (1983) published its occurrence in estuaries of the Gulf of Mexico. In later writings, it has been recorded in salinities less than 15 UPS (Castro-Aguirre and Mora-Pérez, 1984; Rodríguez-Varela et al., 2010; Aguirre-León et al., 2014; Chávez-López et al., 2015).

The ability of $P$. mexicana to withstand high salinities can be explained by biochemical and morphological processes described in other species, such as the secretion of carbohydrates in the intestine (Laverty and Skadhauge, 2015), which causes calcium precipitation and increases the ability to absorb the sodium chloride from hypersaline waters (Whittamore, 2012). Other investigations consider the reduction of branchial permeability by regulating the levels of aquaporin proteins in the branchial epithelia (Tipsmarck et al., 2010; Verkman, 2012), which can be related to changes in the water ingestion rates that increase in fish that colonize saline waters (Nordlie, 2006). Other evidences indicate that it decreases the ionic permeability of the body surface and in the gill ion-secreting cells, that are essential to eliminate large amounts of salts in marine and hyperhaline habitats (González, 2012).

The hyperhalinity of the water did not limit the reproduction of $P$. mexicana. The evidence provided by the females when presenting oocytes and embryos demonstrates the use of energy for reproductive processes, although it is proposed that under conditions of environmental stress the energy budget should be reoriented towards basal physiological maintenance (Stearns, 1992). Even the averages of the number of oocytes (31.3 oocytes/female) and eggs (54.3 eggs/female) were similar to those found in an oligohaline coastal lagoon in the region (ChávezLópez et al., 2015). Furthermore, both the condition factor and the gonadal weight were positively correlated to the length and weight increases. The intervals of these two parameters were similar to those found in females collected in superficial aquatic and cave habitats in southern Mexico (Riesch et al., 2006). 
de estos dos parámetros fueron similares a los encontrados en hembras colectadas en hábitats acuáticos superficiales y de cavernas del sur de México (Riesch et al., 2006).

El promedio de embriones (51,2 embriones/hembra) fue similar al encontrado para hembras del Sistema Lagunar de Alvarado (promedio 58,9 embriones/hembra). Estos valores contrastan con el intervalo de embriones portados por hembras que habitan aguas sulfurosas en cavernas (1-14 embriones) (Tobler y Plath, 2011). Aunque se hubiese esperado un número bajo de huevos y embriones en las hembras de ELEL por la influencia de la hiperhalinidad, los intervalos registrados en ELEL son más aproximados a los registrados en hábitats oligohalinos de la región, lo que indicaría un efecto mínimo de la salinidad en el esfuerzo reproductivo de las hembras.

En otros cyprinodontiformes se ha encontrado que esta respuesta implica altas inversiones de energía para la reproducción, pero el nivel de la condición corporal disminuye como en Gambusia holbrooki (Alcaraz y García-Berthou, 2007). Los aumentos de la salinidad crean niveles de estrés subletales que provocan un gasto de energía mayor por la osmoregulación adicional y reducen la energía destinada para la reproducción, el mantenimiento de la condición corporal y el aprovisionamiento lecitotrófico (Martin et al., 2009).

El análisis de la dieta mostró que el detritus fue el alimento principal de $P$. mexicana, por lo que se le reconoce como consumidor detritívoro (Miller, 2009). Esta especie es capaz de modificar su dieta en diferentes condiciones hidrológicas con base en la disponibilidad de otros alimentos; por ejemplo, se encontraron diferentes especies de algas como alimento principal en especímenes del Sistema Lagunar de Alvarado, Veracruz (Chávez-López et al., 2015). En condiciones extremas de cuevas con aguas sulfurosas de Tabasco, México, se consumieron artrópodos acuáticos principalmente, pero en cuevas con corrientes de agua dulce, se encontró un consumo combinado de detritus con guano de murciélago (Tobler, 2008). Con esta evidencia, la alimentación detritívora de $P$. mexicana destaca como una gran ventaja para sobrevivir en aguas hiperhalinas. Por la vasta disponibilidad del detritus en el estuario, el alimento deja de ser un factor ambiental limitante.

Con base en esta información, P. mexicana es una excepción a las razones que propone Whitfield (2015) para explicar por qué las especies de peces dulceacuícolas están subrepresentadas en los estuarios. La primera razón señala su incapacidad para soportar fisiológicamente intervalos amplios de salinidad. La información que se presenta aquí
The average of embryos (51.2 embryos/female) was similar to that found for females of the Alvarado Lagoon System (average 58.9 embryos/female). These values contrast with the interval of embryos carried by females that inhabit sulfurous waters in caverns (1-14 embryos) (Tobler and Plath, 2011). Although a low number of eggs and embryos would have been expected in ELEL females due to the influence of hyperhalinity, the intervals recorded in ELEL are more approximate to those recorded in oligohaline habitats in the region, which would indicate a minimal effect of salinity in the reproductive effort of females.

In other cyprinodontiforms, this response has been found to imply high energy investments for reproduction, but the level of body condition decreases as in Gambusia holbrooki (Alcaraz and García-Berthou, 2007). Increases in salinity create sub-lethal stress levels that lead to increased energy expenditure due to additional osmoregulation, reducing the energy destined for reproduction, maintenance of body condition, and lecithotrophic provisioning (Martin et al., 2009).

Diet analysis showed that detritus was the main food for P. mexicana, which is why it is recognized as a detritivorous consumer (Miller, 2009). This specie is capable of modifying its diet under different hydrological conditions based on the availability of other foods; for example, different species of algae were found as the main food in specimens from the Lagunar System of Alvarado, Veracruz (Chávez-López et al., 2015). Under extreme conditions in caves with sulphurous waters in Tabasco, Mexico, aquatic arthropods were mainly consumed, but in caves with freshwater currents, combined consumption of detritus with bat guano was found (Tobler, 2008). With this evidence, the detritivorous diet of P. mexicana stands out as a great advantage to survive in hyperhaline waters. Due to the vast availability of detritus in the estuary, food is no longer a limiting environmental factor.

Based on this information, P. mexicana is an exception to the reasons proposed by Whitfield (2015) to explain why freshwater fish species are underrepresented in estuaries. The first reason indicates its inability to withstand physiologically wide salinity intervals. The information presented here revealed the tolerance levels of this species. The second reason refers to adaptation to altered food resources in estuaries compared to freshwater systems. In the case of $P$. mexicana, its detritivorous habits facilitate this condition. The third reason indicates that freshwater 
reveló los niveles de tolerancia de esta especie. La segunda razón se refiere a la adaptación a recursos alimentarios alterados en los estuarios comparados a los sistemas dulceacuícolas. En el caso de P. mexicana, sus hábitos detritívoros le facilitan esta condición. La tercera razón señala que las especies dulceacuícolas no son competidoras hábiles respecto a especies marinas y estuarinas en los estuarios. Aquí se demuestra lo contrario por la mayor abundancia registrada respecto a las especies marinas recolectadas, así como por el mantenimiento de sus procesos reproductivos. La cuarta razón se refiere a su posible combinación en ensamblajes de peces de origen marino y la última razón sugiere que las especies de agua dulce difícilmente logran superar los obstáculos ambientales entre los estuarios y las corrientes de agua dulce. La distribución de P. mexicana en esta región del golfo de México y su ocurrencia en hiperhalinidad señalan una gran capacidad para colonizar hábitats estuarinos en condiciones ambientales extremas.

\section{AGRADECIMIENTOS}

Los autores agradecen a la cooperativa El Llano, Tinajitas y El Viejón, representada por el señor Faustino Carmona Prieto, por las facilidades para la colecta de los especímenes y al señor Sergio Montero "Chaleco" por su apoyo y asistencia durante el trabajo de campo. Este trabajo fue apoyado parcialmente por la División de Investigación de la Facultad de Estudios Superiores Iztacala, Universidad Nacional Autónoma de México, México. species are not skillful competitors with respect to marine and estuarine species in estuaries. Here, the contrary is demonstrated by the greater abundance registered for collected marine species, as well as by the maintenance of their reproductive processes. The fourth reason refers to their possible combination in assemblages of fish of marine origin and the last reason suggests that freshwater species are difficult to overcome environmental obstacles between estuaries and freshwater streams. The distribution of P. mexicana in this region of the Gulf of Mexico and its occurrence in hyperhalinity indicates a great capacity to colonize estuarine habitats in extreme environmental conditions.

\section{ACKNOWLEDGEMENTS}

The authors thank the El Llano, Tinajitas, and El Viejón Cooperative, represented by Mr. Faustino Carmona Prieto, for the facilities for collecting the specimens and $\mathrm{Mr}$. Sergio Montero "Chaleco" for their support and assistance during the fieldwork. This work was partially supported by the Research Division of the Iztacala Faculty of Higher Studies, National Autonomous University of Mexico, Mexico.

\section{BIBLIOGRAFÍA/LITERATURE CITED}

Aguirre-León, A., H. E. Pérez-Ponce y S. Díaz-Ruiz. 2014. Heterogeneidad ambiental y su relación con la diversidad y abundancia de la comunidad de peces en un sistema costero del golfo de México. Rev. Biol. Trop., 62(1): 145-163.

Alcaraz, C. and E. García-Berthou. 2007. Life history variation of invasive mosquitofish (Gambusia holbrooki) along a salinity gradient. Biol. Conserv., 139: 83-92.

Álvarez, J. 1970. Peces mexicanos (claves). Instituto Nacional de Investigaciones Biológicas y Pesqueras, México. 166 p.

Bellinger, G.B. and D.C. Sigee. 2010. Freshwater algae. Identification and use as bioindicators. Oxford University Press. UK. 271 p.

Brito, A. C. 2012. A changing definition of estuary? Adjusting concepts to intermittently closed and open coastal systems. J. Ecosyst. Ecogr., 2(1): $1000 \mathrm{e} 106$. doi: $10.4172 / 2157-7625.1000 \mathrm{e} 106$

Castro-Aguirre, J.L. y C. Mora-Pérez. 1984. Relación de algunos parámetros hidrometeorológicos con la abundancia y distribución de peces en la Laguna de la Mancha, Veracruz. An. Esc. Nal. Cienc. Biol. Méx., 75: 657- 702.

Chávez-López, R., A. Rocha-Ramírez and H. Cortés-Garrido. 2015. Some ecology features of Poecilia mexicana Steindachner, 1863 (Osteichthyes: Poeciliidae) from Alvarado Lagoonal System, Veracruz, Mexico. Am. J. Life Sci., 3(2): 76-84.

De Vlaming, V., G. Grossman and F. Chapman.1982. On the use of the gonosomatic index. Comp. Biochem. Physiol., 73 A: 31 -39.

García, E. 2004. Modificaciones al sistema de clasificación climática de Köppen. Universidad Nacional Autónoma de México, México. 91 p.

González, R. 2012. The physiology of hyper-salinity tolerance in teleost fish: a review. J. Comp. Physiol. B, 182: 321-329.

Hammer, Ø., D.A.T. Harpe and P.D. Ryan. 2001. PAST: Paleontological statistics software package for education and data analysis. Paleont. Electr., 4: 9. 
Ito, T. 1959. The Venice system for the classification of marine waters according to salinity: Symposium on the classification of brackish waters, Venice, 8-14 April 1958. Jap. J. Limnol., 20(3): 119-120.

Laverty, G. and E. Skadhauge. 2015. Hypersaline environments: 85-106. En: Riesch, R., M. Tobler and M. Plath (Eds.). Extremophile fishes. Springer International Publishing, Switzerland. $325 \mathrm{p}$.

Le Cren, E. 1951. The length-weight relationship and seasonal cycle in gonad weight and condition in the perch (Perca fluviatilis). J. Anim. Ecol., 66: 1504-1512.

Martin, S.B., A.T. Hitch, K.M. Purcell, P.L. Klerks and P.L. Leberg. 2009. Life history variation along a salinity gradient in coastal marshes. Aq. Biol., 8: 15-28. doi: $10.3354 / \mathrm{ab} 00203$

Miller, R.R. 2009. Peces dulceacuícolas de México. Comisión Nacional para el Conocimiento y Uso de la Biodiversidad, Sociedad Ictiológica Mexicana A.C., El Colegio de la Frontera Sur y Consejo de los Peces del Desierto México-Estados Unidos. México. 559 p.

Miller, R.R. 1983. Checklist and key to the mollies of Mexico (Pisces: Poeciliidae: Poecilia, subgenus Mollienesia). Copeia, (3): 817-822. Stable URL: http:// www.jstor.org/stable/1444354

Morán-Silva, A., L. Martínez-Flores, R. Chávez-López, F. Contreras, F. Gutiérrez, N. Brown-Peterson and M. Peterson. 2005. Seasonal and spatial patterns in salinity, nutrients, and chlorophyll- $a$ in the Alvarado Lagoonal System, Veracruz, México. Gulf Carib. Res., 17: 133-143.

Needles, L.A., S.E. Lester, R. Ambrose, A. Andren, M. Connor, J. Eckman, B. Costa-Pierce, S.D. Gaines, M.S. Peterson, A. Scaroni, J. Weis and D.E. Wendt. 2015. Managing bay and estuarine ecosystems for multiple services. Estuar. Coast. 38(Suppl.1): S35-S48. doi: 10.1007/s12237-013-9602-7

Nordlie, F.G. 2006. Physicochemical environments and tolerances of cyprinodontoid fishes found in estuaries and salt marshes of eastern North America. Rev. Fish Biol. Fish., 16: 51-106.

Pope, K.L., S.E. Lochman and M.K. Young. 2010. Methods for assessing fish populations: 325-351. In: Quist, M.C. and W.A. Hubert (Eds.). Inland fisheries management in North America. American Fisheries Society, Maryland. 736 p.

Potter, I.C., B.M. Chuwena, S.D. Hoeksemaa and M. Elliott. 2010. The concept of an estuary: A definition that incorporates systems which can become closed to the ocean and hypersaline. Estuar. Coast. Shelf Sci., 87(3): 497-500.

Potter, I.C., J.R. Tweedley, M. Elliott and A.K. Whitfield. 2015. The ways in which fish use estuaries: a refinement and expansion of the guild approach. Fish Fish., 16(2): 230-239. http://onlinelibrary.wiley.com/doi/10.1111/faf.12050/full

Prescott, G.W. 1978. How to know the freshwater algae. W. C. Brown Co., Iowa. 293 p.

Ricker, W.E. 1975. Computation and interpretation of biological statistics of fish populations. Fisheries and Marine Service, Ottawa. 382 p.

Riesch, R., I. Schlupp, M. Tobler and M. Plath. 2006. Reduction of the association preference for conspecifics in cave-dwelling Atlantic mollies, Poecilia mexicana. Behav. Ecol. Sociobiol., 60(6): 794-802. doi:10.1007/s00265-006-0223-z.

Riesch, R., I. Schlupp, R.B. Langerhans and M. Plath. 2011. Shared and unique patterns of embryo development in extremophile poeciliids. PLoS ONE, 6(11): e27377. doi:10.1371/journal.pone.0027377

Rodríguez-Varela, A.C., A. Cruz-Gómez and H. Vázquez-López. 2010. List of ichthyofauna in the Sontecomapan lagoon, Veracruz, México. Biocyt, 3(9): 107121.

Stearns, S.C. 1992. The evolution of life histories. Oxford University Press, Oxford. 249 p.

Tipsmark, C.K., K.J. Sørensen and S.S. Madsen. 2010. Aquaporin expression dynamics in osmoregulatory tissues of Atlantic salmon during smoltification and seawater acclimation. J. Exp. Biol., 213:368-379.

Tobler, M. 2008. Divergence in trophic ecology characterizes colonization of extreme habitats. Biol. J. Linn. Soc., 95: 517-528.

Tobler, M. and M. Plath. 2011. Living in extreme environments: 120-127. In: Evans, J., A. Pilastro and I. Schlupp (Eds.): Ecology and evolution of poeciliid fishes. Chicago University Press, Chicago. 424 p.

Trujillo-Jiménez, P. y B.H. Toledo. 2007. Alimentación de los peces dulceacuícolas tropicales Heterandria bimaculata y Poecilia sphenops (Cyprinodontiformes: Poeciliidae). Rev. Biol. Trop., 55(2): 603-615.

Vazzoler, A. 1996. Biología da reproduçao da peixes teleosteos. EDUEM, São Paulo. 169 p.

Vega-Cendejas, M.E., M. Hernández de Santillana and S. Norris. 2013. Habitat characteristics and environmental parameters influencing fish assemblages of karstic pools in southern Mexico. Neotrop. Ichthyol., 11(4): 859-870.

Verkman, A.S. 2011. Aquaporins at a glance. J. Cell Sci., 124:2107-2112.

Whitfield, A.K. 2015. Why are there so few freshwater fish species in most estuaries? J. Fish Biol., 86: 1227-1250. doi:10.1111/jfb.12641.

Whittamore, J.M. 2012. Osmoregulation and epithelial water transport: lessons from the intestine of marine teleost fish. J. Comp. Physiol. B, 182: 1-39. 